\title{
Unusual Presentation of Lupus in Pediatric Patient: Case Report
}

\author{
Karan Raheja*, P. S. Narang, Satwinder Kapoor, A. J. Chitkara, Nikhil Vinayak, Alok Kalyani \\ Max Hospital, Shalimar Bagh, New Delhi, India \\ Email: *aquariankaran76@gmail.com
}

How to cite this paper: Raheja, K., Narang, P.S., Kapoor, S., Chitkara, A.J., Vinayak, N. and Kalyani, A. (2016) Unusual Presentation of Lupus in Pediatric Patient: Case Report. Open Journal of Rheumatology and Autoimmune Diseases, 6, 102-105.

http://dx.doi.org/10.4236/ojra.2016.64016

Received: August 1, 2016

Accepted: November 12, 2016

Published: November 15, 2016

Copyright $\odot 2016$ by authors and Scientific Research Publishing Inc. This work is licensed under the Creative Commons Attribution International License (CC BY 4.0).

http://creativecommons.org/licenses/by/4.0/

\begin{abstract}
Systemic lupus erythematosus (SLE) is a multisystem disease characterized by loss of self-tolerance resulting in development of autoantibodies and formation of immune complexes. Multiple organ involvement can be seen with renal and neurological involvement carrying the worst prognosis. This case report is of 13-year-old Indian boy who presented with fever and rash, along with Macrophage Activation Syndrome secondary to sepsis. Patient showed improvement in symptoms with steroid therapy and IVIG.
\end{abstract}

\section{Keywords}

Systemic Lupus Erythematosus, Lupus

\section{Case Report}

13 years old child brought with chief complaints of fever since 11 days associated with rash since 7 days, rash was maculopapular with conjunctiva and genitalia sparing. Child was being treated in some hospital as enteric fever and was receiving I.V ceftriaxone and amikacin, as the child was not clinically responding so, was referred to our hospital. At admission child vital signs were febrile (102F), H.R-110 bpm, R.R-20/min, CFT < $3 \mathrm{sec}$, B.P-114/66, on examination child had warm peripheries, generalized rash, ulcers over hard palate, well felt peripheral pulses, cervical lymphadenopathy, swollen lips and systemic examination was within normal limits. Detailed investigations were sent as listed in Table 1. Child was started on Inj. Ceftriaxone (empirically), Tab. Doxycycline (Weil-Felix test-positive) along with supportive therapy. Child's Echo-no evidence of endocarditis and USG Abdomen-mild free fluid in the pelvis. Child's EBV was also sent as child P.S showed few atypical cells, which later turned out to be negative. Child's RFT was deranged and urine routine-showing proteinuria (3+) and hematuria from 
Table 1. Labs at admission.

\begin{tabular}{cccc}
\hline LAB & RESULT & LAB & RESULT \\
\hline WBC & 1.6 & AST & 266 \\
HB & 12 & ALT & 170 \\
PLATELET & 150 & GGT & 241 \\
SODIUM & 129 & LACTATES & 1.1 \\
POTASSIUM & 5 & FERRITIN & $>7500$ \\
CHLORIDE & 118 & ESR & 15 \\
BICARBONATE & 16 & CRP & 0.2 \\
UREA & 39 & PROCALCITONIN & 0.45 \\
CREATININE & 1.49 & C3 COMPLEMENT & 18 \\
PTT & 39.6 & C4 COMPLEMENT & 0 \\
PT & 11 & Anti-dsDNA-Ab & 1042 \\
INR & 1.02 & LDH & 1570 \\
TOTAL PROTEIN & 4.8 & ANA & RBO \\
ALBUMIN & 2.9 & URINALYSIS & PROTEIN 2+ \\
DIRECT BILIRUBIN & 0.8 & & N
\end{tabular}

day-1 of admission, so nephrologist opinion was sought along with rheumatologist as child's ANA report was positive with low $\mathrm{C} 3$ and $\mathrm{C} 4$.

Child was investigated for SLE and HLH, which came to be positive for both. As anti-ds DNA was positive along with high ferritin (>7500) with triglycerides-181 and LDH-1570. So, child was planned for bone marrow and renal biopsy, but as the child's clinical state deteriorated, in form of increase work of breathing and requirement of non-invasive ventilation, so both planned procedure was deferred. Child repeat CRP and Procalcitonin was highly positive and as chest $\mathrm{x}$-ray showed halo signs, so galactomannan was sent and child was added on Inj. Meropenem, Teicoplanin and Clindamycin along with Tab Voriconazole (For Aspergillosis). In view of deterioration child was thought to have MAS secondary to SLE, so was started steroids pulse dose and later maintainence therapyalong with IVIg (for sepsis) at $2 \mathrm{gm} / \mathrm{kg}$. Child's condition stabilized over next 2 - 3 days and BiPAP was removed. Repeat Ferritin (1700), CRP (negative) and Procal (7), all came down significantly. Kidney Biopsy was done later, which showed features of-Focal Lupus activity: ISN/RPS Class $3 \mathrm{~A}$ and indices (NIH) of disease activity $3 / 24 \&$ chronicity $0 / 12$ and child was started on MMF along with steroids. As child's PCR for rickettsia was negative, so Inj. Doxycycline was stopped after 1 week, Inj. Meropenem, Teicoplanin and Clindamycin was stopped after 2 weeks, but T. Voriconazole was being continued for 3 weeks, as galactomannan was positive. Child's blood cultures were sent twice during the stay in hospital, but never grew any organism. Child was discharged to home after 3 weeks of hospital stay, with no rash, fever and 
normal cell count (all 3 cell lines) and renal function test. Child during stay in our hospital didn't require any renal replacement therapy or inotropes.

\section{Discussion}

Etiology, treatment, and prognosis of MAS have mostly been uncertain. In a case study of a patient with SLE and MAS, numerous antibodies (ANA, anti-dsDNA, anti-Sm, anti-RNP, anti-Ro, and peripheral ANCA antibodies) [1] were tested positive. It was thought that the more amount of autoantibodies and immune complexes bound to normal blood cells trigger phagocytosis of those cells and it is possible that the quantity of these autoantibodies and the increased complement activity during a SLE flare can trigger MAS.

After making the diagnosis of MAS, initiation of therapy is important. Most clinicians start with intravenous methylprednisolone pulse therapy $(30 \mathrm{mg} / \mathrm{kg}$ for three consecutive days) followed by $2-3 \mathrm{mg} / \mathrm{kg} /$ day in four divided doses. If a response to steroids is not evident within 24 - 48 hours, parenteral administration of cyclosporine A (CyA; 2 - 7 mg/kg/day) should be initiated [2] [3] [4]. Patients in whom MAS remains active despite the use of corticosteroids and CyA present a serious challenge. IVIG is another treatment option, which is especially useful in patients who are suspected to have an underlying viral infection. Further, the next line of treatment if both steroids and immuno-suppression are not effective is a biologic agent, such as anakinra and rituximab. Anakinra is an IL-1 receptor blocker that has been used effectively in patients with MAS secondary to SLE, which did not respond to steroids, IVIG, and cyclosporine. If MAS, however, is driven by EBV infection, one might consider rituximab, a treatment that would eliminates B-lymphocytes, the main type of cells harboring EBV virus. This approach has been successfully used in EBV-induced lymphoproliferative disease [5]. The patient in our study responded to steroids and IVIG.

Although the reported mortality rates of MAS reach 20\%, due to increasing awareness it is now diagnosed relatively early and the outcome is improving [6]. A substantial proportion of MAS patients experience recurrent episodes and these patients may require closer monitoring. Multiple studies have found no correlation between ferritin levels and the severity of disease or outcome; however, serial ferritin levels may shed more light on prognosis [7]. The patient in this case report had a ferritin of 7500 on initial admission, which decreased to 1700 indicating response to therapy. Once his symptoms improved and his ferritin slowly decreased over the course of weeks. He was safely discharged home with close follow up.

\section{Key Points}

Macrophage activation syndrome (MAS) is a life-threatening complication of rheumatic disease that, for unknown reasons, occurs much more frequently in individuals with systemic juvenile idiopathic arthritis (SJIA) and in those with adult-onset still disease. MAS is characterized by pancytopenia, liver insufficiency, coagulopathy, and neurologic symptoms and is thought to be caused by the activation and uncontrolled prolifera- 
tion of T lymphocytes and well-differentiated macrophages, leading to widespread hemophagocytosis and cytokine overproduction. Signs and symptoms of MAS can mimic an infection or SLE flare, so diagnosing MAS can be difficult. However, increased ferritin and LDH levels are characteristic of MAS and may help distinguish and guide treatment decisions. If diagnosis is uncertain, a bone marrow biopsy can be helpful. The treatment options at this point include high dose steroids, immunosuppression, IVIG, and lastly biologics that neutralize interleukin-1, a cytokine that plays a pivotal role in SJIA pathogenesis, have been tried by some authors.

\section{References}

[1] McGhee, A. (2015) Persistent Fever and Pancytopenia: Lupus Flare vs. Macrophage Activation Syndrome. The Medicine Forum, 16, Article 11.

[2] Hadchouel, M., Prieur, A.-M. and Griscelli, C. (1985) Acute Hemorrhagic, Hepatic, and Neurologic Manifestations in Juvenile Rheumatoid Arthritis: Possible Relationship to Drugs or Infection. The Journal of Pediatrics, 106, 561-566. http://dx.doi.org/10.1016/S0022-3476(85)80072-X

[3] Stéphan, J.L., Koné-Paut, I., Galambrun, C., Mouy, R., Bader-Meunier, B. and Prieur, A.-M. (2001) Reactive Haemophagocytic Syndrome in Children with Inflammatory Disorders. A retrospective Study of 24 Patients. Rheumatology (Oxford), 40, 1285-1292. http://dx.doi.org/10.1093/rheumatology/40.11.1285

[4] Ravelli, A., De Benedetti, F., Viola, S. and Martini, A. (1996) Macrophage Activation Syndrome in Systemic Juvenile Rheumatoid Arthritis Successfully Treated with Cyclosporine. The Journal of Pediatrics, 128, 275-278. http://dx.doi.org/10.1016/S0022-3476(96)70408-0

[5] Balamuth, N.J., Nichols, K.E., Paessler, M. and Teachey, D.T. (2007) Use of Rituximab in Conjunction with Immunosuppressive Chemotherapy as a Novel Therapy for Epstein Barr Virus-Associated Haemophagocytic Lymphohistiocytosis. Journal of Pediatric Hematology/ Oncology, 29, 569-573. http://dx.doi.org/10.1097/MPH.0b013e3180f61be3

[6] Grom, A.A. (2010) Macrophage Activation Syndrome. The Rheumatologist.

[7] Vilaiyuk, S., Sirachainan, N., Wanitkun, S., Pirojsakul, K. and Vaewpanich, J. (2013) Recurrent Macrophage Activation Syndrome as the Primary Manifestation in Systemic Lupus Erythematosus and the Benefit of Serial Ferritin Measurements: A Case-Based Review. Clinical Rheumatology, 32, 899-904. http://dx.doi.org/10.1007/s10067-013-2227-1 
Submit or recommend next manuscript to SCIRP and we will provide best service for you:

Accepting pre-submission inquiries through Email, Facebook, LinkedIn, Twitter, etc. A wide selection of journals (inclusive of 9 subjects, more than 200 journals)

Providing 24-hour high-quality service

User-friendly online submission system

Fair and swift peer-review system

Efficient typesetting and proofreading procedure

Display of the result of downloads and visits, as well as the number of cited articles

Maximum dissemination of your research work

Submit your manuscript at: http://papersubmission.scirp.org/

Or contact ojra@scirp.org 